\title{
Balancing Employer Business Interests and Employee Privacy Interests: A Survey of Kansas Intrusion on Seclusion Cases in the Employment Context
}

\author{
Pamela V. Keller ${ }^{*}$
}

I. INTRODUCTION

Employers have begun using more sophisticated, high-tech methods to monitor employee behavior. Employers test employees for AIDS and drug use; videotape them; electronically monitor their computer use, Internet use, emails, text messages, and phone calls; and track their movements with Global Positioning System (GPS) technology. ${ }^{1}$ Employers can even use radio frequency chips to constantly monitor an employee's location. ${ }^{2}$ While employers clearly have the right to monitor employee behavior, that right is not limitless. The tort of intrusion on seclusion creates one such limit.

The extent to which the intrusion on seclusion tort protects employee privacy under Kansas law is, however, somewhat of a mystery. The Kansas Supreme Court has not yet squarely addressed an employee's intrusion on seclusion claim against an employer or articulated a specific approach to these claims. The Kansas Supreme Court's analysis of intrusion on seclusion claims in the creditor-debtor context does, however, suggest how the court would approach an intrusion on seclusion claim in the employment context. Numerous federal court cases analyzing intrusion on seclusion claims under Kansas law in the employment context also serve as a guide to predicting how Kansas courts would rule on these claims. This Article synthesizes current

\footnotetext{
Clinical Associate Professor and the Robert A. Schroeder Teaching Professor, University of Kansas School of Law. The author thanks KU Wheat Law Library professors and staff for the extensive research they provided for this Article.

1. Robert Sprague, From Taylorism to the Omnipticon: Expanding Employee Surveillance Beyond the Workplace, 25 J. MARSHALl J. COMPUTER \& INFO. L. 1, 3, 34 (2007); see also Shefali N. Baxi \& Alisa A. Nickel, Big Brother or Better Business: Striking a Balance in the Workplace, 4 KAN. J. L. \& PUB. POL'Y 137, 137-38 (1994-1995).

2. Sprague, supra note 1, at 34; see also Rachel Emma Silverman, Tracking Sensors Invade the Workplace, WALL ST. J., Mar. 7, 2013, at B1.
} 
intrusion on seclusion law in Kansas and suggests an approach for Kansas courts to follow when analyzing an intrusion upon seclusion claim in the employment context. It also collects and reviews existing federal cases analyzing intrusion on seclusion claims in the employment context under Kansas law.

Kansas courts should approach an intrusion on seclusion claim in the employment context as they have approached these claims in the creditor-debtor context: Courts must balance the respective rights and interests of the parties. To determine whether an employer has invaded an employee's privacy, courts must determine whether the employer's legitimate business interest in the information outweighs the employee's privacy interest. At least one federal court applying Kansas intrusion on seclusion law has used this approach, and it is consistent with the approach of other states.

Part II summarizes Kansas intrusion on seclusion law, and Part III summarizes that law as applied in the creditor-debtor context. Part IV explains how a balancing of interests similar to that used in the creditordebtor context will operate in the employment context. Part V surveys intrusion on seclusion claims in the employment context under Kansas law, organized by the type of alleged intrusion. The survey also includes some cases analyzing employee privacy claims against a government employer under federal law. Part VI concludes.

The focus of this Article is the intrusion on seclusion tort claim, which is only one part of a web of common law, statutory, and constitutional provisions that purport to protect individuals' privacy. ${ }^{3}$ The Article does not address Kansas statutory or constitutional privacy protections. It does not analyze in any depth federal statutes or privacy violations based on the United States Constitution. Some federal cases

3. For Kansans employed by private employers, the tort "remains the bedrock protection against unwarranted intrusions.” Daniel P. O'Gorman, Looking out for Your Employees: Employers' Surreptitious Physical Surveillance of Employees and the Tort of Invasion of Privacy, 85 NEB. L. REV. 212, 218 (2006) (quoting Jeremy Friedman, Note, Prying Eyes in the Sky: Visual Aerial Surveillance of Private Residences as a Tort, 4 COLUM. SCI. \& TECH. L. REv. 1, 24 (2003)) (internal quotation marks omitted). Federal constitutional provisions generally restrain only government actors, "federal legislation prohibits only surveillance that interferes with employees' self-organizing efforts and activities," and few employees have a contract of employment that would prohibit surveillance or protect particular privacy interests. Id. at 217-18. And Kansas has not enacted a statute generally authorizing a private cause of action for invasion of privacy. See J. Lyn Entrikin, The Right to be Let Alone: The Kansas Right of Privacy 82 (Univ. of Ark. at Little Rock, William H. Bowen Sch. of Law, Research Paper No. 12-05, 2013), available at http://ssrn.com/abstract=215 6111 (noting that the Kansas legislature "has not authorized private claims for invasion of privacy, except under very narrow circumstances involving violation[s] of specific criminal procedure statutes"). 
governing employee privacy claims under the Fourth Amendment are included in the survey because the courts' reasoning might influence a Kansas court's recognition of an employee privacy interest or its balancing of employer-employee interests in an intrusion on seclusion tort claim.

\section{INTRUSION ON SECLUSION IN KANSAS}

The common law right of privacy in Kansas stems from the right to be left alone and to live without the public's unwarranted intrusion into "matters with which the public is not necessarily concerned."4 The right is "relative to the customs of the time and place, and it is determined by the norm of the ordinary man." ${ }^{, 5}$ It is concerned primarily with injury to a person's emotions and mental suffering. ${ }^{6}$

Kansas has adopted the right of privacy as analyzed in the Restatement (Second) of the Law of Torts, chapter 28A. Kansas courts recognize four types of invasion of privacy: (1) unreasonable intrusion on the seclusion of another; (2) appropriation of another's name or likeness; (3) unreasonable publicity given to another's private life; and (4) publicity that unreasonably places the other in a false light before the public. $^{7}$ For an invasion of privacy to be actionable, its manner or nature must "outrage or cause mental suffering, shame, or humiliation in a person of ordinary sensibilities.",

Kansas courts first recognized an intrusion on seclusion claim in Froelich v. Adair. ${ }^{9}$ Liability results when a person (1) intentionally (2) intrudes, physically or otherwise, on the solitude or seclusion of another, or into his private affairs or concerns, and (3) the intrusion is highly

4. Johnson v. Boeing Airplane Co., 262 P.2d 808, 812 (Kan. 1953) (quoting 41 AM. JuR. Privacy § 2).

5. Id. at 813 (quoting 41 AM. JuR. Privacy § 12).

6. Froelich v. Adair, 516 P.2d 993, 996 (Kan. 1973).

7. Vespa v. Safety Fed. Sav. \& Loan Ass'n, 549 P.2d 878, 881 (Kan. 1976) (quoting Dotson v. McLaughlin, 531 P.2d 1, syl. ๆ 1 (Kan. 1982)); see also PIK CIVIL 4TH § 127.61 (2011) (Right of Privacy).

8. Johnson, 262 P.2d at 812 (quoting 41 AM. JuR. Privacy § 2).

9. 516 P.2d at 996 . The Kansas Supreme Court first recognized a common law right of privacy in Kunz v. Allen, 172 P. 532, 532 (Kan. 1918), allowing a plaintiff to recover for the misappropriation of her name or likeness. The court recognized claims for publicity given to private facts in 1972 and false light publicity in 1977. Entrikin, supra note 3, at 15. For a thorough history of the Kansas right of privacy, see generally id. 
offensive to the reasonable person. ${ }^{10}$ Unlike the other privacy torts recognized, intrusion on seclusion does not require publication. ${ }^{11}$

The defendant's intrusion must be intentional. ${ }^{12}$ According to the Restatement (Second), a person acts intentionally when she desires to cause the consequences of her actions or believes the consequences are substantially certain to result from them. ${ }^{13}$ A person need not intend to cause harm, but rather must intend to "bring about a result which will invade the interests of another in a way [the] law forbids." 14 Malice is not required.

Kansas cases do not specifically describe what constitutes solitude or seclusion, but the Kansas Court of Appeals has referred to the idea as an individual's "zone of privacy." For an actionable invasion or intrusion, a defendant must place herself physically, or by means of her senses, within plaintiff's zone of privacy. ${ }^{15}$ The essence of the tort is the right to be left alone, so the defendant must invade an area in which a plaintiff could reasonably expect to be left alone or invade a matter a plaintiff could reasonably consider private. ${ }^{16}$ Thus, this "zone of privacy” likely includes matters or information in which a plaintiff may reasonably expect privacy.

The interference may be a physical intrusion or one in which the defendant uses her sensory faculties. ${ }^{17}$ It may also be by "some other form of investigation or examination into his private concerns, as by opening his private and personal mail, searching his safe or his wallet, examining his private bank account, or compelling him by a forged court order to permit an inspection of his personal documents."18

A person is generally not in seclusion if the person is in public. ${ }^{19}$ And a matter is generally not private if the matter is already exposed to

\footnotetext{
10. Vespa, 549 P.2d at 881.

11. Adair, 516 P.2d at 997; see also RESTATEMENT (SECOND) OF TORTS § 652B cmt. b (1977). Generally, the tort is based on the manner in which an individual obtains information; the intrusion itself creates liability even without publication or use. See Adair, 516 P.2d at 997; see also RESTATEMENT (SECOND) OF TORTS § 652B cmt. b.

12. Intent has not been an issue in most employee intrusion on seclusion claims thus far analyzed under Kansas law. See infra Part V.

13. RESTATEMENT (SECOND) OF TORTS § 8A (1965).

14. See W. Page Keeton et al., Prosser and Keeton on the LaW of Torts § 8, at 36 (5th ed. 1984).

15. Finlay v. Finlay, 856 P.2d 183, 190 (Kan. Ct. App. 1985).

16. See id. at 189-90.

17. Id. at 189 .

18. Id. at 189-90 (citing RESTATEMENT (SECOND) OF TORTS § 652B cmt. b (1977)).

19. See Hartman v. Meredith Corp., 638 F. Supp. 1015, 1018 (D. Kan. 1986) (stating that plaintiffs must show defendant intruded on some aspect of their private affairs and finding that a
} 
the public. ${ }^{20}$ Even in a public place, however, a person may keep some matters from the public gaze and maintain privacy in those matters. Thus, a person does not intrude on another's seclusion by examining public records about her or by observing her on a public street. But an intrusion may occur, for example, if a person takes a picture of a woman's underwear inadvertently exposed while she is walking on a public street. ${ }^{21}$

Determining whether a matter or information is private or public has become increasingly difficult with advancing technologies. So while it may be clear that you do not intrude on a person's seclusion by observing her on a public street, it is not clear, for example, whether you invade her privacy by tracking all her movements on public streets for a long period of time with GPS technology. ${ }^{22}$ Whether a matter or information is private can also be more difficult to discern in the employment context where employers and employees share physical space, property, and information. Determining, for example, whether employees can expect privacy in personal phone calls made on employer-owned phone equipment or in personal files on companyowned computers, involves complex, fact-specific inquiries. ${ }^{23}$

Even if an intrusion on seclusion has occurred, however, it will not be actionable unless it is highly offensive to a reasonable person. An intrusion is highly offensive only when it is a substantial intrusion and the result of conduct to which an ordinary and reasonable person would strongly object. ${ }^{24}$ Whether an intrusion is highly offensive depends on the totality of the circumstances. ${ }^{25}$ Both the manner and nature of the intrusion matter: They must outrage a reasonable person or cause a reasonable person mental suffering or humiliation. ${ }^{26}$

plaintiff bail bondsman standing with clients in open court could not sue a broadcaster for intrusion on seclusion).

20. Peterson v. Moldofsky, No. 07-2603-EFM, 2009 WL 3126229, at*4 (D. Kan. Sept. 29, 2009). Further, "under Kansas law the disclosure of properly obtained information does not constitute an intrusion sufficient to make out a claim of invasion of privacy under the theory of intrusion upon seclusion." Id. at *3.

21. ReStATEMENT (SECOND) OF TORTS § 652B cmt. c.

22. See discussion infra Part V.H.

23. See discussion infra Part V.E-G.

24. Moore v. R.Z. Sims Chevrolet-Subaru, Inc., 738 P.2d 852, 857 (Kan. 1987) (quoting Froelich v. Werbin, 548 P.2d 482, 485 (Kan.1976)).

25. See, e.g., Werner v. Kliewer, 710 P.2d 1250, 1256 (Kan. 1985) (finding that a doctor's disclosure of intimate facts about a mother's mental condition "would ordinarily be highly objectionable," but was not in this case because the doctor communicated the information to a judge responsible for the safety of her children).

26. Johnson v. Boeing Airplane Co., 262 P.2d 808, 812 (Kan. 1953); Moore, 738 P.2d at 856. 
Consent is a complete defense to an intrusion on seclusion claim. ${ }^{27}$ The right to be free from intrusion may also be waived. ${ }^{28}$ Consent and waiver may be implied or inferred from the surrounding circumstances. ${ }^{29}$ Qualified privileges generally apply to invasion of privacy claims, but in at least one instance the Kansas Supreme Court found that a qualified privilege applicable to defamation claims did not apply to intrusion on seclusion because publication is not one of the tort's elements. ${ }^{30}$

The Kansas Supreme Court has not had the opportunity to articulate a clear approach to intrusion on seclusion claims in the employment context. When it has this opportunity, it should balance the rights and interests of employees and employers to determine liability as it has in intrusion on seclusion claims in the collections context.

\section{THE RIGHT TO BE LEFT ALONE IS QUALIFIED BY THE RIGHTS OF OTHERS}

In the collections context, debtors' privacy interests may be limited by creditors' business interests. When a debtor alleges a creditor intruded on her seclusion, Kansas courts explicitly balance the debtor's rights against the rights of creditors. ${ }^{31}$ In this context, "the right to be left alone is qualified by the rights of others.”32 The Kansas Supreme Court

27. Entrikin, supra note 3, at 34; see also PIK CIVIL 4TH § 127.62 (2011); RESTATEMENT (SECOND) OF TORTS § 892A(1) (1979) ("One who effectively consents to conduct of another intended to invade his interests cannot recover in an action of tort for the conduct or for harm resulting from it.”). Consent may more appropriately be considered part of the plaintiff's case as opposed to consent being an affirmative defense the defendant must prove. Consent prevents the conduct from constituting an actionable invasion. See Entrikin, supra note 3, at 33-34.

28. See Johnson, 262 P.2d at 814; see also Vespa v. Safety Fed. Sav. \& Loan Ass’n, 549 P.2d 878, 881 (Kan. 1976)

29. Johnson, 262 P.2d at 814; PIK CIVIL 4TH § 127.62; Entrikin, supra note 3, at 23, 35.

30. Kansas courts have generally said that intentional tort privileges for communication torts (defamation, libel, slander) also apply to invasion of privacy claims. See, e.g., Dominguez v. Davidson, 974 P.2d 112, 121 (Kan. 1999) (indicating privilege defenses apply to both defamation and invasion of privacy claims); see also Rawlins v. Hutchinson Publ'g Co., 543 P.2d 988 (Kan. 1975). However, the Adair court held that the privilege for communications made in judicial proceedings, which is applicable in defamation suits, did not apply to intrusion on seclusion. Froelich v. Adair, 516 P.2d 993, 997 (Kan. 1973). The Adair court's position "has been criticized as 'dubious' and inconsistent with the consensus in other states that the set of qualified privileges applicable to defamation law generally applies to claims for invasion of privacy." Entrikin, supra note 3, at 36 n.165 (citing DAVID A. ELDER, PRIVACY TORTS § 2:13 (2002)).

31. Moore v. R.Z. Sims Chevrolet-Subaru, Inc., 738 P.2d 852, 857-58 (Kan. 1987) (quoting Dawson v. Assocs. Fin. Servs., 529 P.2d 104, 110 (Kan. 1974)); see also Lowe v. Surpas Res. Corp., 253 F. Supp. 2d 1209, 1237 (D. Kan. 2002).

32. Moore, 738 P.2d at 857 (quoting Dawson, 529 P.2d at 110). 
first explained this idea in Dawson v. Associates Financial Services Co. of Kansas. ${ }^{33}$ Citing an Alabama Supreme Court decision, it stated:

A creditor has and must have the right to take reasonable action to pursue his debtor and collect his debt. But the right to pursue the debtor is not a license to outrage the debtor. The problem of defining the scope of the right to privacy in the debtor-creditor situation is the problem of balancing the interest of the creditor in collecting his debt against that of the debtor in his own personality. ${ }^{34}$

Thus, creditors are "given some latitude to pursue reasonable methods of collecting debts" even though the methods embarrass or inconvenience the debtor. ${ }^{35}$ By accepting credit, "the debtor impliedly consents for the creditor to take reasonable steps to pursue payment even though it may result in actual, though not actionable, invasion of privacy." ${ }^{36}$ The creditor's actions must be reasonable, and the debtor is protected only from oppressive and outrageous conduct. ${ }^{37}$

Similarly, in the employment context, employers may have legitimate business reasons for actions that potentially invade an employee's privacy. Employers must have the right to protect their interests, but that right is not a license to outrage the employee. As in the creditor-debtor cases, defining the scope of the right to privacy in an employer-employee case requires balancing the legitimate business interests of the employer against the privacy rights of the employee.

\section{KANSAS EMPLOYER-EMPLOYEE CASES}

One federal district court in Kansas has relied on creditor-debtor parallels in the employer-employee context. In Ali v. Douglas Cable Communications, the court explicitly balanced employee privacy interests against employer business interests when analyzing an employee intrusion on seclusion claim against an employer. ${ }^{38}$

In Ali, the plaintiffs were customer service representatives whose primary duties were handling customer phone calls about sales, complaints, and the collection of delinquent accounts. ${ }^{39}$ Douglas Cable

33. 529 P.2d 104 (Kan. 1974).

34. Id. at 110 (quoting Norris v. Moskin Stores, Inc., 132 So. 2d 321, 323 (Ala. 1961)).

35. Id. at 110 .

36. Id.

37. Id.

38. 929 F. Supp. 1362, 1382 (D. Kan. 1996).

39. Id. at 1372 . 
Communications (DCC) began extensively recording and monitoring their calls for training and supervision purposes. ${ }^{40}$ DCC notified employees about the monitoring, but DCC recorded the employees' work and personal calls for a period of time before it notified them. ${ }^{41}$ Among other things, the employees claimed DCC's actions intruded on their seclusion. ${ }^{42}$

In ruling on the employer's summary judgment motion, the court found that the monitoring of work-related phone calls was neither an intrusion into the plaintiffs' zone of privacy nor highly offensive to a reasonable person. ${ }^{43}$ The monitoring of personal calls was, on the other hand, an actionable intrusion into their privacy. ${ }^{44}$ "Without uncontroverted proof that the plaintiffs knew their personal calls would be recorded," the court could not find that their expectation that those calls would remain private was unreasonable as a matter of law. ${ }^{45}$ Thus, a reasonable jury could find the monitoring invaded their zone of privacy.

The court then considered whether the employer's actions were justified, which required a balancing test. “The employer's asserted interest in recording the phone calls 'must be balanced against the degree of intrusion resulting from the employer's methods to obtain the information." "46 Ultimately the court found that a reasonable jury could conclude that DCC's conduct in recording the employees' personal calls was not justified. ${ }^{47}$

Thus, the federal court in Ali analyzed the intrusion claim in two parts. First, it determined whether the employees had a reasonable expectation of privacy or "zone of privacy" in their personal telephone calls. Then it analyzed whether the employer's business interest justified the degree of intrusion, leading to the ultimate question of whether a reasonable jury could find the intrusion was highly offensive to a reasonable person.

\footnotetext{
40. Id. at 1373 .

41. Id.

42. Id. at 1381.

43. Id. at 1382 .

44. Id.

45. Id.

46. Id. at 1383 (quoting Pulla v. Amoco Oil Co., 882 F. Supp. 836, 837 (S.D. Iowa 1994), aff'd in part, rev'd in part on other grounds, 72 F.3d 648 (8th Cir. 1995)). In support, the court also cited the balancing of interests in the creditor-debtor context under Kansas law. Id. (citing Dawson v. Assocs. Fin. Servs. Co., 529 P.2d 104, 110 (Kan. 1974)).

47. Id.
} 
Courts in other jurisdictions have similarly balanced employeremployee interests in intrusion on seclusion claims in the employment context. $^{48}$ Some have done so specifically in the second part of the intrusion analysis, determining whether the alleged intrusion is highly offensive. $^{49}$

The approach is also similar to the privacy analysis for employee claims under the Fourth Amendment of the United States Constitution. ${ }^{50}$ When a government employee claims a constitutional violation based on an employer's intrusion into privacy for allegedly work-related purposes, courts first analyze whether the employee has a reasonable expectation of privacy in the information, matter, or place. ${ }^{51}$ Then, the government

48. A tentative draft of the Restatement (Third) of Employment Law collects several intrusion on seclusion cases balancing the employer's legitimate business interests against the employee's privacy interest:

Bratt v. Int'l Bus. Machines Corp., 392 Mass. 508, 520, 467 N.E.2d 126, 135 (1984) (“In evaluating whether the information sought from employees could amount to an unreasonable interference with their right of privacy, we stated that the employer's legitimate interest in determining the employees' effectiveness in their jobs should be balanced against the seriousness of the intrusion on the employees' privacy."); Vargo v. Nat'l Exch. Carriers Ass’n, Inc., 870 A.2d 679, 686 (N.J. Super. Ct. App. Div. 2005) ("[W]hether there is a common law violation requires a court to balance the employer's interest with the prospective employee's reasonable expectation of privacy.”); Borse v. Piece Goods Shop, Inc., 963 F.2d 611, 625 (3d Cir. 1992) (“[D]etermining whether an alleged invasion of privacy is substantial and highly offensive to the reasonable person necessitates the use of a balancing test.") (applying Pa. law); Wilcher v. City of Wilmington, 60 F. Supp. 2d 298, 302 (D. Del. 1999) ("Delaware courts have repeatedly recognized that the right of privacy is not an absolute right, but a right that is qualified by the circumstances and the rights of others.”) (applying Del. law).

RESTATEMENT (THIRD) OF EMPLOYMENT LAW § 7.06 reporters’ notes cmt. a (Tentative Draft No. 5, 2012).

49. Id.

50. The expectations an employee has against government intrusion may be different than an employee's expectations against private employer intrusions. Similarly, a government employer's business rights and interests may be different than those of a private employer. The balancing approach, however, makes sense in both contexts. See RESTATEMENT (THIRD) OF EMPLOYMENT LAW § 7.01 reporters' notes cmt. d (Tentative Draft No. 5, 2012) (“The Supreme Court’s approach to employee privacy interests has a federal constitutional, rather than a common-law, basis. However, the Court's analysis of the constitutional protections accorded to government workers has employed a balancing test that would appear equally appropriate in the common-law context.”).

51. City of Ontario v. Quon, 130 S. Ct. 2619, 2628-29 (2010). This test reflects most closely the plurality approach in O'Connor v. Ortega, 480 U.S. 709 (1987). The plurality suggested courts determine (1) whether a search implicates Fourth Amendment rights because the employee has a reasonable expectation of privacy, and (2) whether the employer's intrusion on that privacy is reasonable under the circumstances. Id. at 717-19, 725-26 (plurality opinion). To determine a Fourth Amendment violation in the employment context, Justice Scalia would determine whether a search would be "regarded as reasonable and normal in the private-employer context." Id. at 731-32 (Scalia, J., concurring). When using Justice Scalia's approach to determine if a search would be regarded as reasonable and normal in the private employer context, courts have specifically examined whether the search would be an intrusion on seclusion under state tort law. See, e.g., 
employer's intrusion on that expectation is "judged by the standard of reasonableness under all the circumstances." 52 The intrusion "is reasonable if it is justified at its inception and if the measures adopted are reasonably related to the objectives of the search and not excessively intrusive in light of the circumstances giving rise to the search."53 Thus, courts balance the invasion of the employee's reasonable expectations of privacy against the government employer's "need for supervision, control, and the efficient operation of the workplace."54 In both tort and Fourth Amendment analysis, therefore, the law recognizes that an employer's legitimate business interests must justify intrusion on an employee's privacy. ${ }^{55}$

When analyzing intrusion on seclusion claims, Kansas courts should use the balancing approach of the Ali court and other state courts. To determine an employer's liability, the court should first determine if the employer intentionally intruded into the employee's zone of privacy or a matter or information in which the employee had a reasonable expectation of privacy. If so, the court should determine whether that intrusion was highly offensive by balancing the defendant's legitimate business interest against the employee's privacy interest. This explicit two-step approach will allow for a clearer development of the law, which is especially important given the tort remains one of the few available privacy protections for employees of nongovernment employers.

Even as to the first inquiry, determining whether an employee has a legally protectable privacy interest or zone of privacy, a defendant employer's business interest may be relevant. ${ }^{56}$ Employers generally

Richards v. Cnty. of Los Angeles, 775 F. Supp. 2d 1176, 1185 (C.D. Cal. 2011); Carter v. Cnty. of Los Angeles, 770 F. Supp. 2d 1042, 1050 (C.D. Cal. 2011).

52. Quon, 130 S. Ct. at 2630 (quoting O’Connor, 480 U.S. at 725-26 (plurality opinion)).

53. Id. at 2630 (quoting $O^{\prime} C o n n o r, 480$ U.S. at 725-26) (internal quotation marks omitted).

54. Thompson v. Johnson Cnty. Cmty. Coll., 930 F. Supp. 501, 508 (D. Kan. 1996) (quoting O'Connor, 480 U.S. at 719-20) (internal quotation marks omitted), aff'd, No. 96-3223, 1997 WL 139760 (10th Cir. 1997), and aff'd sub nom. Boyer v. Johnson Cnty. Bd. of Cnty. Comm'rs, 108 F.3d 1388 (10th Cir. 1997).

55. The Kansas Supreme Court used a similar balancing of interests to determine if sheriffs were liable for intrusion on seclusion when they entered a plaintiff's home without a warrant. Monroe v. Darr, 559 P.2d 322, 327 (Kan. 1977). The court first found that entering plaintiff's home was an intrusion on his privacy. It then stated: "Such intrusion, unless justified by the circumstances, would constitute an actionable invasion of ... privacy." Id. (citing RESTATEMENT (SECOND) OF TORTS § 652B (1977); Froelich v. Adair, 516 P.2d 993 (Kan. 1973); Dotson v. McLaughlin, 531 P.2d 1 (Kan. 1975); Jeffrey F. Ghent, Annotation, Uninvited Entry into Another's Living Quarters As Invasion of Privacy, 56 A.L.R.3D 434 (1974) and cases cited therein.).

56. See, e.g., Ali v. Douglas Cable Commc’ns, 929 F. Supp. 1362, 1382 (D. Kan. 1996). The court found that monitoring work-related phone calls was not a substantial intrusion on employees because of the employer's interest in monitoring the calls: 
$\mathrm{own}^{57}$ and control the workplace, and thus are to some level responsible for what occurs there. ${ }^{58}$ Employers must be able to maintain and control their property and monitor employees to ensure they perform their jobs in a satisfactory, efficient, and safe manner. ${ }^{59}$ Because of these interests, different expectations for privacy will exist in the workplace than in other contexts. ${ }^{60}$ Employer policies and business practices will also shape employees' privacy expectations. ${ }^{61}$

An explicit balancing of interests is necessary, however, to determine whether the intrusion is one that would be highly offensive to a reasonable person. An intrusion should not be highly offensive if the employer's legitimate business need outweighs the employee's privacy interest. As the importance of the privacy interest and the intrusiveness of the employer's actions increase, so too must the employer's showing of a business need. ${ }^{62}$ The level of business interest must be sufficient to justify the invasion. ${ }^{63}$ Both the scope and manner of the employer's

The plaintiffs cannot reasonably claim any offensive intrusion by the monitoring or recording of their business calls at the work place. Such calls were made for the benefit and in the interest of their employer. The business calls were a large part of the plaintiffs' responsibilities at work, and the defendants were simply monitoring the plaintiffs' work performance.

Id.

57. Ownership of an item is not dispositive, but it is an important consideration in determining privacy interests. See, e.g., United States v. Angevine, 281 F.3d 1130, 1134-35 (10th Cir. 2002) (examining whether for Fourth Amendment purposes a professor had reasonable expectation of privacy in an office computer).

58. See Restatement (ThiRD) OF EMPloyment LAW $\S 7.01 \mathrm{cmt}$. b (Tentative Draft No. 5, 2012).

59. See id.

60. Id.

61. See City of Ontario v. Quon, 130 S. Ct. 2619, 2629-30 (2010) (noting that clearly communicated employer policies will shape employees' reasonable expectations of privacy); see also Angevine, 281 F.3d at 1134 (“[E]mployees” expectations of privacy ... may be reduced by virtue of actual office practices and procedures ....” (quoting O’Connor v. Ortega, 480 U.S. 709, 717 (1987))).

62. Cf. Willner v. Thornburgh, 928 F.2d 1185, 1187-88 (D.C. Cir. 1991) ("The protections of the Fourth Amendment are graduated in proportion to the privacy interests affected. Decreasing levels of intrusiveness require decreasing levels of justification.”).

63. The tentative draft of the Restatement (Third) of Employment Law outlines the scope of wrongful employer intrusions:

Courts have focused on two aspects of the intrusion in judging its offensiveness: the purpose of the intrusion and the method of the intrusion. A legitimate business purpose or public interest must justify the intrusion itself and its manner and scope. In some cases, the strength of the business purpose or public interest will determine the reasonableness of the manner or scope of the intrusion; for example, an important interest will justify an invasive intrusion, whereas meager justification will not justify the same intrusion. The inquiry is necessarily context-specific.

RESTATEMENT (THIRD) OF EMPLOYMENT LAW § 7.06 cmt. a (Tentative Draft No. 5, 2012). 
intrusion must be reasonable in light of the employee's privacy interest. Even if the employer has a legitimate purpose for its intrusion, the means used must also be reasonable as balanced against the employee's privacy interest. $^{64}$

Explicitly balancing the rights of employers and employees will ensure courts consider the degree to which an employer has a legitimate business need for the information when determining the extent to which an employee's privacy right is qualified or limited. That inquiry may be more complex than it is in the creditor-debtor context. The creditor's interest is simply to recover the debt; an employer will have a variety of business interests it needs to protect. ${ }^{65}$

This balancing approach would appropriately be used to determine liability for alleged intrusions both on and off employer property. Determining liability gets more complex as employees leave the employer's work site and work from home or other personal spaces (e.g., a friend's home, a hotel room, or a personal vehicle). As home and office life merge, employers can more easily argue for a business need to inquire into or monitor employee behavior away from the employer's business site. ${ }^{66}$ This reality suggests employees need an explicit balancing of employer and employee interests to hold on to whatever privacy rights they currently have. An employer must be required to justify the degree of its intrusion based on the importance or scope of its business interest, or any business interest could arguably justify an invasion of an employee's private matters.

This balancing approach would also appropriately be used to resolve claims involving employer monitoring of on-duty and off-duty conduct. ${ }^{67}$

64. This is consistent with Kansas intrusion on seclusion law outside the employment context. Both the nature and manner of the intrusion must be highly offensive to a reasonable person. See Johnson v. Boeing Airplane Co., 262 P.2d 808, 809 (Kan. 1953); see also Moore v. R.Z. Sims Chevrolet-Subaru, Inc., 738 P.2d 852, 856 (Kan. 1987).

65. An employer may want to monitor an employee for a variety of reasons. An employer may want to monitor work activities for performance issues or to determine the most productive manufacturing method. It might want to determine if employees are violating work rules or want to monitor certain physical areas to ensure employee and client safety. It might want to monitor employee use of company equipment, including company vehicles, or determine if employees are using alcohol or illegal drugs. It might monitor off duty behavior if it suspects an employee on medical leave or receiving workers' compensation is not honestly representing her condition. See O'Gorman, supra note 3, at 219-22. Employers pursued many of these business interests in the cases included in the following survey. See infra Part V. But even when an employer's business interest is legitimate, that interest must be balanced against the employee's privacy interest to determine whether the employer's intrusion is highly offensive and, thus, whether the employer has violated the employee's common law right to privacy.

66. See Sprague, supra note 1, at 33.

67. See id. (examining the propriety of employers expanding surveillance beyond the 
It would apply, for example, to an employer who investigated an employee's off-duty behavior to determine the validity of the employee's claim that she was entitled to workers' compensation benefits. A court would first determine if the investigation invaded a private matter or private information and then determine whether the employer's business need for the information justified the scope of the intrusion and the means used. The balancing approach would also apply to resolve a claim based on an employer's monitoring of an employee's or prospective employee's postings on social media sites or personal blogs. ${ }^{68}$ The analysis would first turn on whether the employee has a reasonable expectation of privacy in the online information. If the employee could establish the information was private, the court would then balance the employee's privacy interest against the employer's legitimate business interest to determine if the employer intruded on the employee's seclusion. ${ }^{69}$

Courts should balance the parties' respective interests as part of assessing whether a plaintiff has established the elements of the intrusion on seclusion tort (specifically in determining whether the employer's actions were highly offensive to a reasonable person). While an employer might also allege a legitimate business purpose in support of an affirmative defense or privilege, a court should balance employer and employee interests in the first instance as it considers the sufficiency of the plaintiff's case. This is consistent with Kansas courts' analysis of the intrusion on seclusion tort in the creditor-debtor context, with the Ali court's analysis, with the privacy analysis in the Fourth Amendment context, and with the suggested approach of the tentative draft of the Restatement (Third) of Employment Law. Each approach examines the

workplace and noting that when courts have found employers to have at least potentially invaded an employee's privacy, “it is usually because the employer has pried into an employee's private life far beyond a legitimate business need").

68. See Patricia Sanchez Abril et al., Blurred Boundaries: Social Media Privacy and the Twenty-First-Century Employee, 49 AM. Bus. L.J. 63, 108, 112, 123-24 (2012) (positing that Millennial employees maintain an expectation of privacy regarding information disclosed on social media, yet current law does not offer meaningful protections for employees' social media privacy).

69. Absent new statutory protections, this balancing approach may be the employee's best chance to limit employer prying that does not relate to a legitimate business interest. As to personal information on social media, Kansas employees may have some statutory protection in the near future. As this Article was submitted for publication, Kansas lawmakers introduced legislation preventing employers from asking employees to divulge social media information. The legislation would prohibit employers from requesting or requiring applicants or employees to disclose (1) whether they have a social media site or website, or (2) the password or other form of access to the site. See H.B. 2092, 1-24, Kan. H.R., 2013 Sess. (Kan. 2013); S.B. 53, 1-18, Kan. Sen., 2013 Sess. (Kan. 2013). 
reasonableness of the employer's actions to determine whether a wrongful intrusion occurred.

\section{CASE SURVEY}

Federal district courts in Kansas have considered claims of employer intrusions into employees' bodies, bodily functions, personal information, work areas, computer files, and telephone and electronic communications. Thus far employers have fared well and prevailed on most claims. Employees have, however, survived various dispositive motions when they have asserted a privacy interest in their bodies, medical information, personal phone calls, and personal computer files.

Although some employers have tried to argue it, existing cases do not support the claim that employees have no zone of privacy in the workplace (the first part of the intrusion analysis). Two federal courts have rejected employer claims that an employee can never have a reasonable expectation of privacy in the workplace under Kansas law, ${ }^{70}$ although neither federal court could cite a specific Kansas case for this principle. While it may be more difficult to establish a zone of privacy in matters, information, or property that employers and employees share, nothing in Kansas intrusion on seclusion law suggests an employee automatically loses all rights to privacy while working.

Federal cases analyzing Kansas law make up the bulk of the following survey. As mentioned, the Kansas Supreme Court has had little occasion to analyze an employee's claim of intrusion on seclusion against an employer, ${ }^{71}$ but federal courts have repeatedly ruled on such claims under Kansas law. The Kansas Supreme Court has looked to federal cases analyzing Kansas law for guidance in reaching decisions on

70. Topolski v. Chris Leef Gen. Agency Inc., No. 11-2495-JTM, 2012 WL 984278, at *3 (D. Kan. Mar. 22, 2012); Greenhorn v. Marriot Int'l, Inc., 258 F. Supp. 2d 1249,1261 (D. Kan. 2003).

71. The Kansas Supreme Court has opined whether an employer would be liable for an intrusion on seclusion claim if it released certain employee personnel records. An employer raised the issue as a defense to a discovery dispute in an employee's discrimination claim against it. The case is included in the survey. See infra Part V.C. The court also examined an employee's privacy claim against an employer in Munsell v. Ideal Food Stores, 494 P.2d 1063 (Kan. 1972). At the time, the Restatement (Second) of Torts recognized only one form of invasion of privacy. See Entrikin supra note 3, at 37 n.172. The jury instruction in Munsell referred to the "wrongful intrusion of one's private activities," which is the equivalent of intrusion on seclusion. Munsell, 494 P.2d at 1074. The facts of the case, however, gave rise to a claim of false light publicity, and the court seemed to analyze this type of privacy claim and not intrusion on seclusion. See id. Insofar as the employee claimed his employer's questions were an intrusion, the court seemed to find the questions were justified by a business purpose-determining if the employee falsified time records. Entrikin, supra note 3, at 36-39. 
other privacy tort claims, so it likely would do the same if faced with an intrusion on seclusion claim in the employment context. ${ }^{72}$

Also included are a handful of Tenth Circuit and United States District Court of Kansas cases analyzing employees' reasonable expectations of privacy under federal law. To the extent these cases analyze employees' reasonable expectations of privacy in the workplace, they may help predict the extent to which Kansas courts would find an intrusion into an employee's private matters or information (the first part of the intrusion analysis). Also, to the extent these cases balance government employer and employee interests, some parallels may be made to suggest an appropriate balance of interests in the private employer-employee context (the second part of the intrusion analysis). A few recent United States Supreme Court cases balancing the legitimate interests of government employers and employees and one United States Supreme Court case examining individuals' reasonable expectations of privacy in the Fourth Amendment context as to the government's use of GPS technology are also included. The latter case is included for how it might bear on an employer's analysis of whether its use of GPS technology could intrude on employee privacy.

\section{A. Bodies-Sexual Harassment and Sexual History}

Employees claiming sexual harassment have sometimes also sought to recover for intrusion on seclusion. When the conduct consists of inappropriate touching or sexual comments, federal courts generally have dismissed the claims on the basis that the harassment is not a sufficient intrusion on the plaintiff's solitude or prying into her private concerns. Courts seem to have struggled to determine whether the inappropriate conduct fit within the gravamen of the intrusion tort-whether the inappropriate conduct actually pried into or invaded a plaintiff's private affairs. They may have hesitated to expand the intrusion on seclusion tort to provide a remedy given that federal and state discrimination statutes already provide specific remedies for sexual harassment in the employment context. One federal court did, however, conclude that inappropriate sexual conduct may be actionable as an intrusion on seclusion when the conduct involves coercive sexual demands.

Occasional grabbing, touching, rubbing of shoulders, and sexual comments did not amount to an actionable intrusion into the solitude or

\footnotetext{
72. See, e.g., Dominguez v. Davidson, 974 P.2d 112, 121 (Kan. 1999) (quoting Ali v. Douglas Cable Commc'ns, 929 F. Supp. 1362, 1383 (D. Kan. 1996)).
} 
seclusion of a plaintiff's physical being in Haehn v. City of Hoisington. ${ }^{73}$ These allegations were not "intrusive or coercive sexual demands" on plaintiff such that they examined her private concerns or improperly inquired "into her personal sexual proclivities and personality.,"74 Similarly, in Maus v. Belger Cartage Service, Inc., the court found repeated obscene gestures, messages, or jokes were not an invasion of privacy. ${ }^{75}$ The court noted the alleged harasser did not make "inquiries" into plaintiff's sex life. ${ }^{76}$ In Maus, the plaintiff also alleged an instance of sexual battery, but the underlying facts of the battery do not appear in the opinion and, thus, it is unclear how severe or offensive the battery was. ${ }^{77}$ A manager's single vulgar remark that an employee could "sit on [his] face" was also found not to be an intrusion into an employee's sexual proclivities or privacy. ${ }^{78}$ Most recently, in Topolski v. Chris Leef General Agency Inc., a federal court again held that unwanted sexual advances and physical touches were insufficient to support an intrusion on seclusion claim. ${ }^{79}$

It is possible, however, for the circumstances of a sexual harassment claim to suggest an actionable intrusion on seclusion. In Greenhorn v. Marriott International, Inc., the federal court distinguished a supervisor's actions as far more serious and invasive than those in Maus because the supervisor's actions included coercive sexual demands of a highly offensive and intrusive nature. ${ }^{80}$ The court, therefore, refused to dismiss the plaintiff's intrusion on seclusion claim against her

73. 702 F. Supp. 1526, 1532 (D. Kan. 1988).

74. Id. (quoting Phillips v. Smalley Maint. Servs., Inc., 711 F.2d 1524, 1536 (11th Cir. 1983)).

75. No. 96-1257-JTM, 1996 WL 748056, at *3 (D. Kan. Dec. 27, 1996).

76. Id.; cf. Pascouau v. Martin Marietta Corp., No. 98-1099, 1999 WL 495621, at *14 (10th Cir. July 14, 1999) (finding that coworkers bothering plaintiff with "inappropriate, prying questions about her sex life and sexual preferences" did not alone support a claim for intrusion on seclusion under Colorado law because, even if inappropriate or offensive, the questions revealed nothing and thus were not an invasion of privacy).

77. Maus, 1999 WL 495621, at*1.

78. Wolf v. Burum, No. 88-1233-C, 1990 WL 81219, at *11 (D. Kan. May 16, 1990).

79. No. 11-2495-JTM, 2012 WL 984278, at *1, *3 (D. Kan. Mar. 22, 2012) (alleging supervisor touched plaintiff and forced her to listen to stories about his sexual exploits). The rulings in these cases are consistent with the outcome of an earlier case, Ulrich v. K-Mart Corp., 858 F. Supp. 1087 (D. Kan. 1994), although the Ulrich court's reasoning differs. In Ulrich, the court dismissed a privacy claim at summary judgment even though an employee alleged her supervisor stroked, grabbed, kissed, and touched her on her breasts and between her legs. Id. at 1090, 1095. Plaintiff did not allege the harasser made coercive sexual demands or exposed a private part of his body. Id. at 1090. The court did not analyze whether the alleged harasser had invaded plaintiff's physical person, but rather found no intrusion on seclusion because the conduct occurred in a shared work area, not a private place. Id. at 1095 . The more recent cases mentioned above shift the focus from whether a private place was invaded to whether the employee's personal privacy was invaded.

80. 258 F. Supp. 2d 1249, 1261-62 (D. Kan. 2003). 
employer. ${ }^{81}$ The plaintiff alleged her supervisor sexually harassed her over an extended period of time. ${ }^{82}$ The supervisor's actions included describing to plaintiff various sexual encounters in graphic detail and then touching plaintiff on her arms and neck; kissing plaintiff without her consent and then attempting to kiss her additional times; and exposing his erect penis to plaintiff and then telling her that if she valued her job she would perform oral sex on him. ${ }^{83}$ The court found the coercive sexual demands potentially pried into plaintiff's private affairs or otherwise intruded on the solitude or seclusion of her physical being. ${ }^{84}$

In Greenhorn, the court did not use a balancing test, but it was unnecessary in that case because the employer clearly had no legitimate business interest in that particular intrusion. By contrast, a government employer argued it had a legitimate business reason for forcing an employee to disclose information about personal sexual matters in Eastwood v. Department of Corrections. ${ }^{85}$ A state corrections department questioned an employee about her sexual history after she alleged another employee had assaulted and molested her following a department training session. ${ }^{86}$ The Tenth Circuit rejected the department's argument that its invasion of privacy was justified because the questions were designed to test the validity of the employee's complaint. $^{87}$ The court reasoned that little correlation exists between a plaintiff's sexual history and whether she fabricated her claim that she was molested; therefore, the court refused to sanction this kind of questioning. $^{88}$

\section{B. Bodily Functions-Drug Testing Cases}

Drug testing does not automatically violate an employee's privacy rights, but it does have the potential to do so because it necessarily invades the employee's private affairs - her bodily functions or bodily

81. Id. at 1262 .

82. Id. at 1253.

83. Id. at $1252-53$.

84. Id. at 1261-62; cf. Daponte v. Ocean State Job Lot, No. WC-02-0646, 2009 WL 3328478 (R.I. Super. Ct. Mar. 4, 2009)' (finding that assault claims and privacy claims do not equate and that nonconsensual touching at the workplace, even if an assault, does not always amount to an invasion of privacy, especially where touching occurred in public location), aff'd, 21 A.3d 248 (R.I. 2011).

85. 846 F.2d 627, 630 (10th Cir. 1988) (arguing that the "State may legitimately inquire into the sexual conduct of its citizens ... to determine if a claim of sexual harassment is well-founded").

86. Id. at 629 .

87. Id. at 631 .

88. Id. 
fluids. ${ }^{89}$ Federal courts have upheld private employer drug testing and rejected claims that a drug test, or the means used to drug test, intruded on employees' seclusion. In at least two Tenth Circuit cases, however, drug tests were found to violate the Fourth Amendment.

A federal district court found no invasion of privacy when an employer, consistent with a written policy, required an employee to provide a urine sample for a drug test to detect marijuana use. ${ }^{90}$ In Frye $v$. IBP, Inc., a meat processing plant had a policy stating that when employees have illegal drugs present in their system, "they become a safety hazard to themselves and their fellow employees." "In light of this policy, and the employer's objective to provide a "safe, clean and wholesome place to work," ${ }^{92}$ the employer was reasonable in seeking a drug test to determine whether its lead mechanic was smoking marijuana. $^{93}$

In another case, a nurse challenged not the drug test itself, but the manner in which the employer conducted it. ${ }^{94}$ The nurse consented to random drug testing as a condition of continued employment after her employer caught her under the influence of Demerol she stole from the hospital. $^{95}$ She claimed the manner of testing invaded her privacy because her female supervisor observed her collecting her urine samples in a bathroom off a public hallway. The bathroom had only one toilet, but the supervisor would enter and remain in the bathroom with the nurse. The supervisor would crouch in front of or beside the nurse while she collected the sample, but she did not actually view the nurse's urine entering the specimen cup. ${ }^{96}$ The court found no invasion of privacy in either the hospital's purpose for obtaining the private information or the means the hospital used. ${ }^{97}$ The hospital's purpose-preventing falsified tests-was proper, especially because the nurse did not challenge that

89. See Haire v. Peterson, No. 12CV6965, 2012 WL 6656912 (D. Kan. Dec. 21, 2012) (acknowledging drug testing creates the potential for an invasion of privacy because it necessarily delves into a person's private affairs); Frye v. IBP, Inc., 15 F. Supp. 2d 1032, 1041 (D. Kan. 1998) (suggesting employers are not prohibited from conducting drug tests under Kansas law because section 44-706(b) of the Kansas Statutes, dealing with employee rights to unemployment benefits, allows employers to require drug testing as a condition of employment).

90. Frye, 15 F. Supp. 2d at 1042.

91. Id. at 1036.

92. Id.

93. Id. at 1042 .

94. Jones v. HCA Health Servs. of Kan. Inc., No. 94-1412-JTM, 1998 WL 159505, at *16 (D. Kan. Mar. 9, 1998).

95. Id. at $* 1, * 4$.

96. Id. at $* 4$.

97. Id. at $* 16$. 
she consented to observed, random drug testing as a condition of employment. ${ }^{98}$ The court also found that even though the situation was uncomfortable and embarrassing, a reasonable person would not strongly object to the means the hospital used to acquire the information, and the hospital's actions were not so far out of the ordinary as to be actionable. $^{99}$

In the Fourth Amendment context, the Tenth Circuit found that an employer's business interest did not justify a random drug test of a city truck driver when he had no advance warning that he would or could be subject to the test. ${ }^{100}$ The court stated that "[ $\left.t\right]$ his sort of unwarned testing is the most intrusive possible, contravening all of one's reasonable expectations of privacy."101 The city's business interest in the information was diminished because the driver was not a new employee whose work habits were unknown. ${ }^{102}$ Rather, the driver had worked for more than a decade with no signs of drug or alcohol abuse, and the employee had been on leave for a year, so the test would not have revealed whether the employee was impaired on the job. ${ }^{103}$ Thus, the city's diminished interest had to give way to the driver's expectation of privacy. ${ }^{104}$

The Tenth Circuit later struck a city drug testing policy that sought to randomly test mechanics working on city trash trucks. ${ }^{105}$ Following the United States Supreme Court decision in Chandler v. Miller, ${ }^{106}$ the Tenth Circuit held that although the city had a legitimate interest in ensuring workplace and public safety, it had shown no special need to drug test its mechanics. ${ }^{107}$ The city did not have evidence of a drug problem among its mechanics, or that drug use caused accidents or raised other safety concerns in its trash department. ${ }^{108}$ Moreover, the city's policy was not designed to effectively detect or deter drug use because it was administered at predictable intervals-every four years when an employee renewed her commercial driver's license-and gave

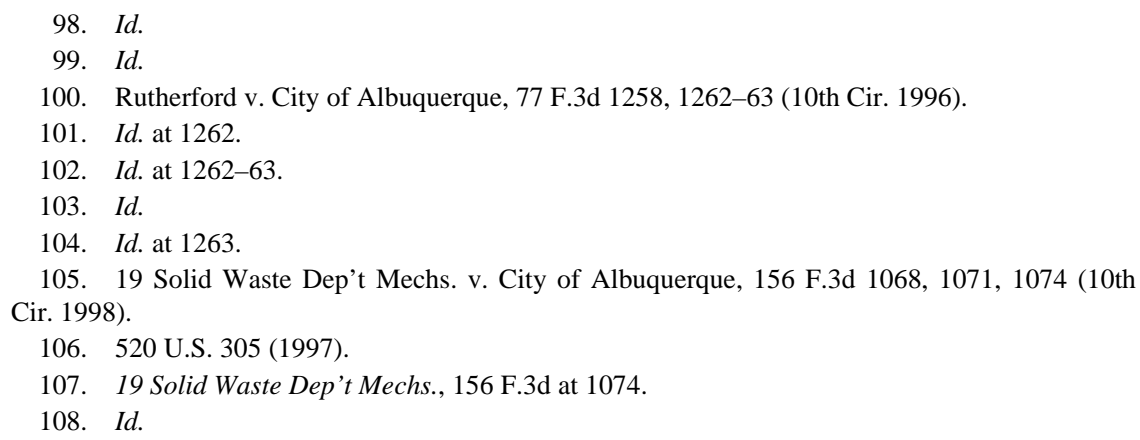


employees sufficient advance notice for them to avoid using drugs before the test. ${ }^{109}$ The city's daily scrutiny of the mechanics' work would serve as a better deterrent than its drug testing policy. ${ }^{110}$ Absent a special need for this type of suspicionless drug testing, the court found the testing violated the Fourth Amendment. ${ }^{111}$

\section{Personal Information-Personnel Records, Time Sheets, Medical Information, Investigations, and Background Checks}

In general, employees do not have an actionable privacy interest in information an employer gathers and maintains in personnel records, insofar as that information directly relates to the employer's management of the workplace or is otherwise available as public information. Courts have, however, acknowledged an employee privacy interest in more sensitive information such as medical records. In some cases, courts have intuitively, if not explicitly, balanced the employee's privacy interest against the employer's business need for the information. For example, an employer's unjustified pursuit of medical information did support an employee's intrusion on seclusion claim against that employer. By contrast, an employer's reasonable investigation of complaints that an employee's alcohol use was affecting his work was not an intrusion on seclusion. Explicitly balancing employer and employee interests in a privacy claim grounded in the United States Constitution, the United States Supreme Court concluded that even if a government employee has a privacy interest in certain personal information acquired in a background check, inquiries about recent drug use, financial integrity, abuse of alcohol or drugs, mental or emotional stability, and general behavior and conduct are lawful.

\section{Personnel Records}

As to publicly recorded facts-such as arrest and conviction records - contained in an employer's files, an employee likely has no reasonable expectation of privacy. The Kansas Supreme Court had occasion to consider the privacy an employee might reasonably expect in her personnel records in Atchison, Topeka \& Santa Fe Railway Co. v. Lopez. ${ }^{112}$ In Lopez, an applicant filed a discrimination complaint with

109. Id.

110. Id.

111. Id. at $1074-75$.

112. 531 P.2d 455 (Kan. 1975). 
the Kansas Commission on Civil Rights after the railway denied him employment. ${ }^{113}$ The Commission then sought the arrest and conviction records of all employees hired into a particular classification over a year to determine the employer's typical use of this information. ${ }^{114}$ One of the railway's arguments against the subpoena was that it would subject itself to liability for an invasion of privacy tort if it produced the records. ${ }^{115}$ The Kansas Supreme Court rejected the argument because it found the information sought was public and not private. ${ }^{116}$ It reasoned that arrests are frequently made in public and publicized in the news media, and that court records, with only limited exceptions, are generally open to the public to view. ${ }^{117}$ Because the facts disclosed were not private, ${ }^{118}$ no liability for invasion of privacy would result if the employer provided the information to the commission. ${ }^{119}$

Employees similarly do not have a reasonable expectation of privacy in their time sheets. The Tenth Circuit addressed this issue in the Fourth Amendment context in McCarty v. City of Bartlesville. ${ }^{120}$ The city fired two police officers it believed had falsified time records. In the course of the employment investigation and a subsequent criminal investigation, other police officers viewed the plaintiffs' time sheets. ${ }^{121}$ After a criminal prosecution of the officers failed, the city rehired them, but the officers then sued for various alleged constitutional violations including a privacy violation. ${ }^{122}$ The privacy claim was dismissed. The court found the employees had no objectively reasonable expectation of privacy in their time sheets because they did not own the documents, the

\footnotetext{
113. Id. at 460 .

114. Id.

115. Id. at 469 .

116. Id.

117. Id.

118. Given their duties owed to the public, public officials may expect even less privacy in their employment records than their counterparts in the private sector. See Wisconsin Newspress, Inc. v. Sch. Dist., 546 N.W.2d 143, 150 (Wis. 1996) (“[A] prominent public official, or official in a position of authority, should have a lower expectation of privacy regarding his or her employment records.”).

119. Lopez, 531 P.2d at 470. This is similar to the Kansas Court of Appeals' finding in Robison v. Board of County Commissioners, that an individual has "at best only a limited privacy interest in his criminal history record at the [Kansas Bureau of Investigation] central depository.” No. 93,992, 2007 WL 518829, at *7 (Kan. Ct. App. Feb. 16, 2007). The court further found that because criminal charges are public information, discovery and disclosure of information contained in those records does not amount to an intrusion on seclusion. Id.

120. 8 F. App’x 867 (10th Cir. 2001).

121. Id. at $870-72$.

122. Id. at 872 .
} 
documents were not in their control, and they did not take-nor could they take-steps to maintain privacy in the time sheets. ${ }^{123}$

\section{Medical Records}

The sensitive nature of medical records distinguishes them from the personnel records discussed above. Courts have acknowledged that medical information is generally private, but an employer can seek medical information that directly relates to an employee's job. When an employer can justify the need for the medical information and has employed reasonable means to gather it, it can likely successfully defend an intrusion on seclusion claim. For example, medical records providing information only about the injuries causing plaintiff to miss work were not sufficiently confidential to support a privacy claim under the Fourth Amendment in Ortlieb v. Howery. ${ }^{124}$ The employee, a medical technologist at a city hospital, severely fractured her leg on an outing with other hospital employees. She was initially taken to the same city hospital, and a number of doctors and fellow employees treated her there. ${ }^{125}$ When the employee later requested an indefinite extension of leave to recover from her injuries, her supervisor-one of the hospital doctors-retrieved her $\mathrm{x}$-rays and viewed them without her permission. ${ }^{126}$ Based on his review of the $\mathrm{x}$-rays and his understanding of her condition, the supervisor determined plaintiff would never be able to fully perform her job duties, so he denied the leave and terminated her employment. ${ }^{127}$ The court found that the employee did not have an absolute right to privacy in her x-rays. ${ }^{128}$ The information that the employee had a severely broken leg was well known by hospital employees, and because she supported her request for leave with a doctor's report stating her continuing disability was corroborated by the $\mathrm{x}$-rays, she had no reasonable expectation of privacy in them. ${ }^{129}$ Also, unlike written medical records, the x-rays contained no intimate or personal information that would support a reasonable expectation of privacy. ${ }^{130}$

\footnotetext{
123. Id. at 876-78.

124. 74 F. App’x 853 (10th Cir. 2002).

125. Id. at 855 .

126. Id.

127. Id.

128. Id. at 856-57.

129. Id. at 857.

130. Id.
} 
On the other hand, an employer may invade an employee's privacy when it gathers an employee's medical information absent a legitimate business need for it. In Lankford v. City of Hobart, ${ }^{131}$ the Tenth Circuit found a reasonable jury could conclude the city violated an employee's privacy under federal law when she produced evidence the city police chief seized and reviewed her private medical records. ${ }^{132}$ The employee alleged the police chief sexually harassed her, and that when she rebuffed his advances he retaliated by, among other things, spreading rumors she was a lesbian. ${ }^{133}$ The plaintiff also alleged the police chief "used his authority as chief of police to obtain [her] private medical records without her consent from a local hospital in an attempt to discredit her or to prove his statements that she was a lesbian."134 Citing various federal cases, the Tenth Circuit found "no question that an employee's medical records, which may contain intimate facts of a personal nature, are well within the ambit of materials entitled to privacy protection.”135

An employer may violate an employee's rights if the means it uses to gather the employee's medical information is unreasonable. Thus, an employee's allegation that her employer "badger[ed] and harass[ed]" the employee's physician for medical information while the employee was on leave was sufficient to state a claim of intrusion on seclusion. ${ }^{136}$ In Blackwell v. Harris Chemical North America, Inc., the plaintiff employee suffered a serious medical condition that prevented her from working. ${ }^{137}$ She requested, and her employer granted, a leave of absence under the Family and Medical Leave Act of $1993 .{ }^{138}$ She alleged that while she was on leave, her employer harassed and badgered a nurse at her physician's office for confidential information regarding her illness and treatment. ${ }^{139}$ While the court found the employer's alleged conduct was not sufficiently outrageous to support a claim for intentional infliction of emotional distress, it found the alleged conduct was sufficiently offensive to support an intrusion on seclusion claim. ${ }^{140}$ In

\footnotetext{
131. 27 F.3d 477 (10th Cir. 1994).

132. Id. at 479 .

133. Id. at 478 .

134. Id.

135. Id. at 479-80 (quoting Woods v. White, 689 F. Supp. 874, 876 (W.D. Wis. 1988)) (internal quotation marks omitted); see also Mangels v. Pena, 789 F.2d 836, 839 (10th Cir. 1986); Tavoulareas v. Wash. Post Co., 724 F.2d 1010, 1020 (D.C. Cir.1984)).

136. Blackwell v. Harris Chem. N. Am., Inc., 11 F. Supp. 2d 1302, 1310 (D. Kan. 1998).

137. Id. at 1305.

138. Id.; see also 29 U.S.C. §§ 2601-2654 (2006).

139. Blackwell, $11 \mathrm{~F}$. Supp. 2d at 1305.

140. Id. at 1309-10.
} 
refusing to dismiss plaintiff's claim, the court apparently found the medical information was private, and that, if proved, the employer's conduct could be highly offensive, but it did not explain why in detail. The employer may have had no legitimate business interest in the medical information it sought or its business interest may not have justified its actions (or both). ${ }^{141}$

\section{Employer Investigations and Background Checks}

Courts seem to intuitively, if not explicitly, balance the rights of employers and employees to determine whether an employer's investigation of employee behavior intrudes on the employee's seclusion. In Curtwright v. Ray, ${ }^{142}$ the federal district court found a company's investigation into the extent to which its president's alcohol use was affecting his performance was not an intrusion on his seclusion. ${ }^{143}$ The company's board of directors were informed that salesmen had complained about problems related to the president's drinking, and some requested he not come into their territory because of it. ${ }^{144}$ The board investigated the complaints by interviewing particular company employees by telephone and then terminated the president. ${ }^{145}$ The court found the president agreed to the investigation and so had opened his affairs up to inspection. ${ }^{146}$ He therefore did not "cloak" his affairs to keep them private, and so the court found no intrusion. ${ }^{147}$ Although it did not say so explicitly, the court seemed influenced by the company's legitimate business need to determine and control plaintiff's work performance.

The United States Supreme Court, in NASA v. Nelson, ${ }^{148}$ upheld the government's right as an employer to conduct employee background checks that inquire about recent drug use, financial integrity, abuse of alcohol or drugs, mental or emotional stability, general behavior and conduct, and other matters. ${ }^{149}$ The plaintiffs were NASA contract

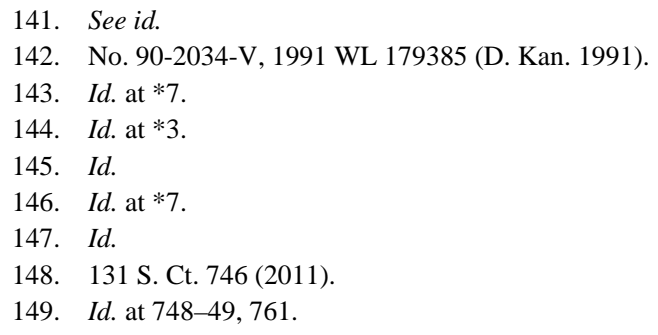


employees, many of whom worked for the agency for many years. ${ }^{150}$ They objected to the government's new requirement that contract employees undergo the same background check as the NASA civil servants. ${ }^{151}$ That background check required them to fill out a form asking, among other things, whether the employee has "used, possessed, supplied, or manufactured illegal drugs in the last year."152 If an employee answered yes, she had to provide additional detail, including whether she received treatment or counseling. ${ }^{153}$ The employee also had to sign a release authorizing the government to obtain personal information from schools, employers, and others during its investigation. ${ }^{154}$ The government sent a questionnaire to references asking open-ended questions including whether the reference had adverse information about the employee's honesty or trustworthiness, violations of the law, financial integrity, abuse of alcohol or drugs, mental or emotional stability, general behavior or conduct, and other matters. ${ }^{155}$ Once received by the government, the information acquired would be subject to the federal Privacy Act. ${ }^{156}$ The Act prohibits, subject to exceptions, the government from disclosing the information without the employee's written consent. ${ }^{157}$

The employees did not challenge the background check as an impermissible search or seizure under the Fourth Amendment, but rather contended the check violated a "constitutional right to informational privacy.”158 The Court declined to determine whether a constitutional right to informational privacy exists. Instead, it assumed the challenged inquiries into the employees' personal information implicated "a privacy interest of constitutional significance." 159 It then held that, "whatever the scope of this interest," the government could lawfully conduct these background checks given that the information revealed was "subject to the Privacy Act’s safeguards against public disclosure."160

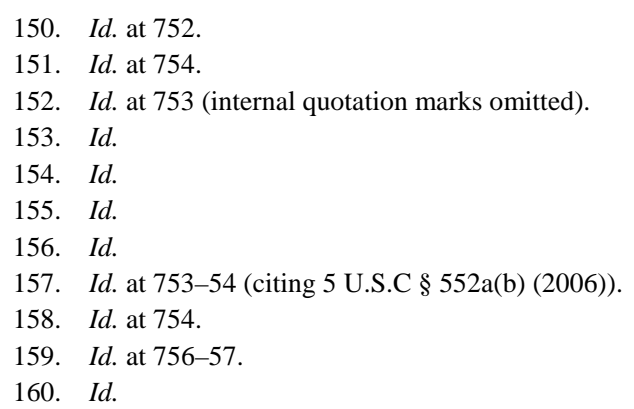


The Court reasoned that the government had a legitimate interest in conducting basic employment background checks because the investigations help ensure the security of government facilities and the employment of a competent, reliable workforce. ${ }^{161}$ The employees perform important work, "funded with a multibillion dollar investment from the American taxpayer," so the government has a strong interest in understanding more about the contract employees who are "minding the store."162 The Court found the questions about drug use on the employee form to be reasonable because "the Government is entitled to have its projects staffed by reliable, law-abiding persons who will 'efficiently and effectively' discharge their duties." 163 And it found the more open-ended questions to references "reasonably aimed at identifying capable employees who will faithfully conduct the Government's business."164 The open-endedness of the questions also allowed the government to separate "strong candidates from weak ones." 165

\section{Work Areas-Locker Areas}

Analyzing employee claims under the Fourth Amendment, a federal district court held that security personnel did not have a reasonable expectation of privacy in an unlocked, unenclosed locker area to which numerous employees had access. ${ }^{166}$ The area was located in a room that also housed the building's heating and cooling equipment, and few people other than the security officers routinely entered the room. ${ }^{167}$ The court found the employer, a community college, acted reasonably when it videotaped (without sound) the locker area to investigate reports of theft and of employees improperly bringing firearms to work. ${ }^{168}$

Also analyzing an employee claim under the Fourth Amendment, the Tenth Circuit found that, even if an employee has a reasonable expectation of privacy in a locker, a government employer may search the locker if it has legitimate grounds to believe the employee stole

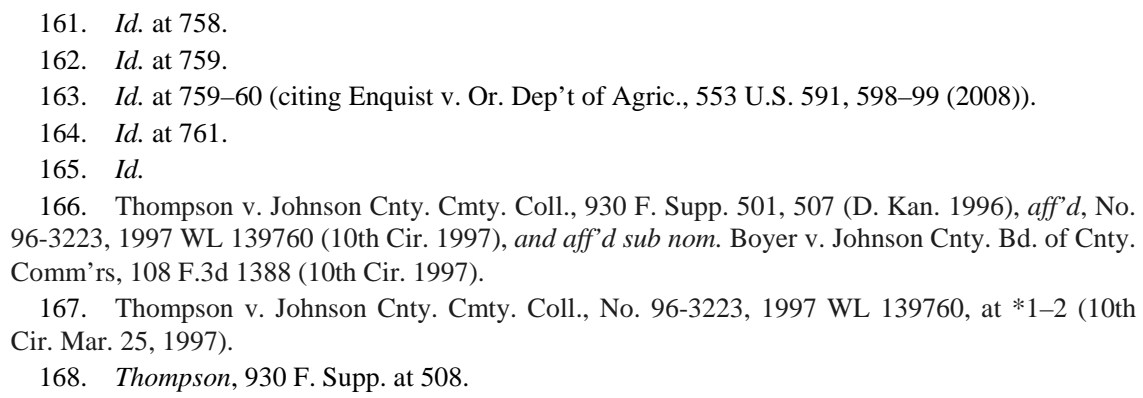


employer property and placed it there. ${ }^{169}$ The court balanced the employee's legitimate privacy interest in her locker against the government employer's interest in completing work promptly and efficiently, and it concluded the search was proper. ${ }^{170}$

\section{E. Computer Files}

A few federal cases address the extent to which employees have a legitimate expectation of privacy in work computers under federal constitutional law. In one case, the Tenth Circuit found an employee had no reasonable expectation of privacy in an employer-owned computer, and in another it found an employee had no reasonable expectation of privacy in a personal computer the employee brought to work. A federal district court, however, found that an employee may have a reasonable expectation of privacy in personal files on a work computer. Employer policies and actual workplace practices weighed heavily in the privacy interest analysis in each case. Employers who notified employees they would monitor and access computer data files, and then instituted workplace practices consistent with those policies, did in fact limit or eliminate their employees' privacy interest. But an employer who allowed employees to have personal files on their work computers, and who did not actually monitor those computers, left open the possibility that its employees had a reasonable expectation of privacy in their personal computer files.

The Tenth Circuit rejected an employee's claim he had a reasonable expectation of privacy in an office computer in United States $v$. Angevine City. ${ }^{171}$ The employee tried to hide that he viewed over 3,000 images of child pornography. ${ }^{172}$ His employer, Oklahoma State University, had a very specific computer policy aimed at reducing or eliminating any employee privacy interest in office computer data. ${ }^{173}$ The policy stated the university (1) had the right to view any file stored or passing through the computer; (2) would in fact periodically monitor data; (3) kept logs of erased data and could determine who erased it; and (4) would monitor and access employee computer data and stored files if it suspected wrongdoing. ${ }^{174}$ The university's ownership of the equipment, the lack of

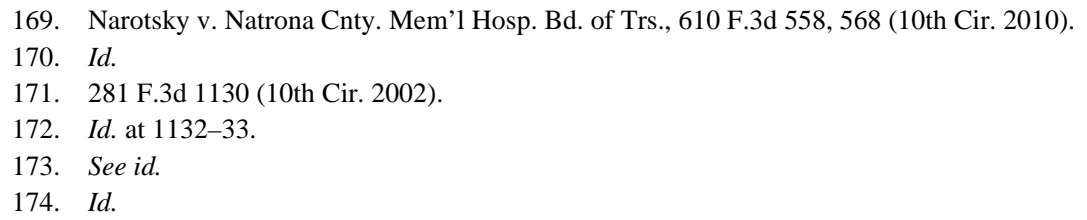


immediate control the employee had of his data, and the employee's failure to take any steps to maintain privacy in his computer all contributed to the court's finding that the employee had no reasonable expectation of privacy in his computer data. ${ }^{175}$

The Tenth Circuit also approved a warrantless search of an employee's personal computer that he brought to work and connected to the government employer's computer network. In United States $v$. Barrows a county treasurer shared a workspace with the county clerk in an open area of city hall. ${ }^{176}$ To avoid having to share a computer with the clerk, the treasurer brought in his home computer and connected it to the county computer network. ${ }^{177}$ Shortly after, the clerk had trouble accessing files on his computer and suspected the treasurer's computer might be causing the problem. ${ }^{178}$ With another person's assistance, the clerk searched the treasurer's computer to find the source of the computer problems and in doing so he found files containing child pornography. ${ }^{179}$ In denying the treasurer's motion to suppress in the criminal case against him, the Tenth Circuit found the treasurer had no reasonable expectation of privacy in the computer even though he owned it and not all files on it were accessible to others. ${ }^{180}$ Because he voluntarily brought it to a public space and took no steps to limit others' access to the computer-by password protecting it or shutting it off-his subjective expectation of privacy was unreasonable. ${ }^{181}$

In contrast, in Haynes v. Office of the Attorney General Phill Kline, the federal district court found an employee may have a reasonable expectation of privacy in certain personal files on a work computer. ${ }^{182}$ The court considered the issue on a motion for preliminary injunction, so it did not make a finding on the merits. ${ }^{183}$ The court did, however, conclude that the question was substantial and a fair ground for litigation even though the employee was aware of the government's written policy that employees "shall [have] no expectation of privacy in using [the computer] system." 184 The following facts were sufficient to raise

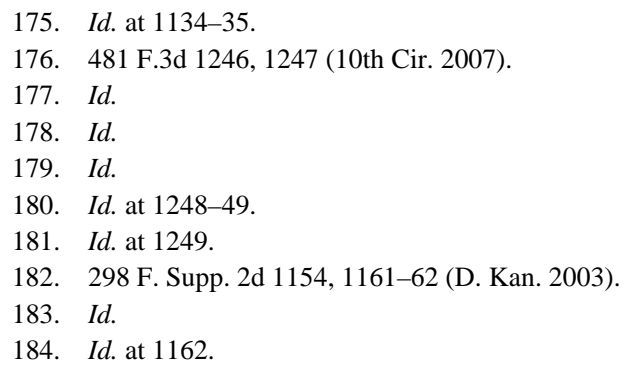


serious issues whether the employee reasonably expected privacy in some personal files: employees were permitted to make private communications using their work computers; employees were taught to create "public" and "private" files; employees were advised they were prohibited from accessing another employee's email; and the government submitted no evidence it had ever monitored or viewed employees' private files or emails. ${ }^{185}$

\section{F. Telephone and Electronic Communications}

An employer does not intrude on another's seclusion simply by listening to an unlawfully acquired audiotape of a private conversation, but it may intrude on an employee's seclusion by taping personal phone calls without the employee's knowledge if it does not discourage the employee from making personal calls on the employer's phone system. ${ }^{186}$

An employer does not intrude on another's seclusion simply by listening to an unlawfully acquired audiotape of a private conversation. In Fields v. Atchison, Topeka, \& Santa Fe Railway Co., an employer received in the mail a letter and a tape of private conversations between one of its managers and another employee. ${ }^{187}$ The letter alleged the two employees were having an affair. ${ }^{188}$ The employer did not know who recorded or sent the tape, nor did the employer record employee conversations on its phones. ${ }^{189}$ The employer played the tape in front of the manager, confirmed it was his voice on the tape, and then fired the manager. ${ }^{190}$ The court rejected the manager's argument that the employer invaded his privacy by listening to the tapes after knowing they were surreptitiously taped without consent. ${ }^{191}$ Listening, alone, was not an intrusion absent evidence the employer authorized or was otherwise involved in the original taping. ${ }^{192}$

As already mentioned, the federal district court in Ali found that employees could reasonably expect privacy in their personal phone calls,

185. Id.; see also People v. Wilkinson, 859 N.Y.S.2d 356, 361 (N.Y. Onondaga Cnty. Ct. May 22,2008 ) (holding police officers had a reasonable expectation of privacy in their work computers because employer's policy allowed, and possibly encouraged, personal use of the computer if it was of "minimal or no cost to the taxpayer").

186. Ali v. Douglas Cable Commc’ns, 929 F. Supp. 1362, 1382 (D. Kan. 1996).

187. 985 F. Supp. 1308, 1310 (D. Kan. 1997).

188. Id.

189. See id. at 1310-11.

190. Id. at 1310.

191. Id. at 1311-13.

192. Id. at 1312-13. 
even when those calls were made on an employer-owned phone. ${ }^{193}$ An employer's monitoring of those personal phone calls on work time could also be highly offensive to a reasonable person. ${ }^{194}$ In Ali, the employer did not discourage employees from making personal calls and did not notify the employees of the monitoring. The court upheld the monitoring of work-related calls but not the monitoring of personal phone calls. ${ }^{195}$ While the employer could justify the former, it could not justify the latter.

\section{G. Text Messages}

The United States Supreme Court held in City of Ontario v. Quon that a city did not violate its employee's Fourth Amendment rights when it reviewed his personal text messages on a city-provided pager without a warrant. $^{196}$

The city purchased pagers capable of sending and receiving text messages and gave them to members of its SWAT team, including plaintiff Quon. ${ }^{197}$ Under the service contract for the pagers, each pager was allotted a limited number of characters to be sent or received each month. If an employee used more characters, the city had to pay an additional fee. ${ }^{198}$ Before acquiring the pagers, the city issued a policy stating that it "reserves the right to monitor and log all network activity including e-mail and Internet use, with or without notice. Users should have no expectation of privacy or confidentiality when using these resources."199 Although the policy did not specifically apply to the pagers, Quon's supervisor informed him and other employees that the policy would apply. ${ }^{200}$

Quon and several other officers repeatedly exceeded the monthly character allotment. ${ }^{201}$ For several months, the city allowed employees to reimburse the city for the overages rather than audit the employees' texts. Eventually, however, the city audited employee text message

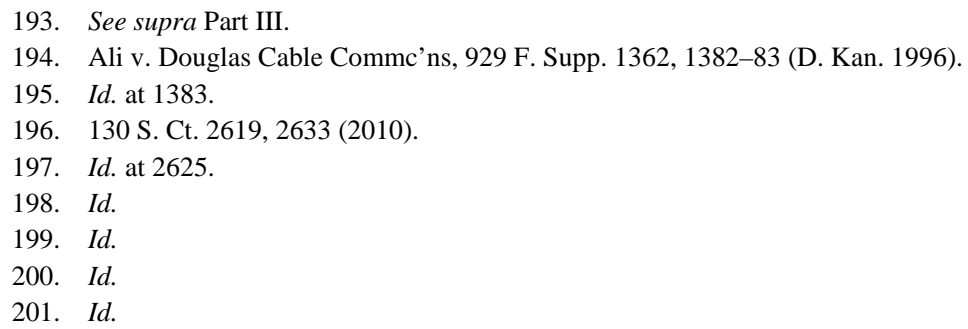


use. $^{202}$ It contacted the service provider and received transcripts of text messages that Quon and others sent over a two-month period. ${ }^{203}$ Investigators used Quon's work schedule to redact the messages sent while off-duty. ${ }^{204}$ A review of his work-time texts revealed numerous non-work-related texts and some sexually explicit content. ${ }^{205}$ Quon was apparently disciplined for his conduct. ${ }^{206}$

The United States Supreme Court did not decide whether Quon had a reasonable expectation of privacy in the text messages. That inquiry was unnecessary because, even if Quon had a reasonable expectation of privacy in his personal texts, the city's warrantless review of the pager transcript was reasonable because it was motivated by a legitimate workrelated purpose and its scope was not excessive. ${ }^{207}$ The city had a legitimate interest in (1) determining whether the existing character limit was sufficient and (2) ensuring it did not force employees to pay out of their own pockets for work-related expenses. ${ }^{208}$ The city had reasonable grounds for suspecting the audit was needed for these work-related purposes, and the means it used were not excessively intrusive (because of the limited time frame and the use of redacted transcripts). ${ }^{209}$ The Court also found that because the city had a legitimate reason for the search, and it was not excessively intrusive, the search would be "regarded as reasonable and normal in the private employer context."210

In declining to determine whether Quon had a reasonable expectation of privacy in his text messages under the circumstances of his case, the Court noted the difficulty of predicting how technology will shape employees' privacy expectations and the "degree to which society will be prepared to recognize those expectations as reasonable."211 It noted that, on the one hand, the pervasiveness of cell phone and text message communications may strengthen the case for an expectation of privacy. "On the other hand, the ubiquity of those devices has made them generally affordable, so one could counter that employees who need cell

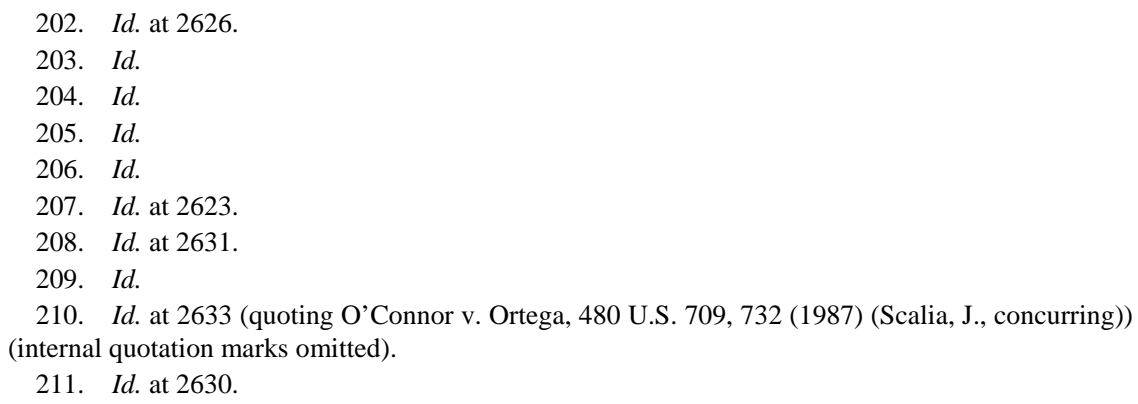


phones or similar devices for personal matters can purchase and pay for their own."212 The Court further confirmed that employer policies concerning communications will shape employees' reasonable expectations, "especially to the extent that such policies are clearly communicated." 213

\section{H. GPS Tracking}

Employers are increasingly using GPS technology to keep track of employees and equipment. ${ }^{214}$ Although courts have upheld the use of this technology to track employees in employer-owned vehicles, privacy issues may still arise when an employee uses the vehicle for work and private purposes and the employer continues to track the vehicle on the employee's personal time.

A federal district court ruled that an employer's GPS monitoring of an employee in a company-owned vehicle on the employee's personal time did not intrude on the employee's seclusion. ${ }^{215}$ In reaching its decision, the district court relied in part on Fourth Amendment case law upholding the propriety of government use of beeper-assisted surveillance in the criminal law context. ${ }^{216}$ Since this district court ruling, however, the United States Supreme Court has specifically addressed whether the government's use of GPS monitoring violates the Fourth Amendment's prohibition against unreasonable searches. In United States v. Jones, the United States Supreme Court held that the government's attachment of a GPS tracking device to a person's vehicle, for the purpose of obtaining information about the person, is a search within the meaning of the Fourth Amendment. ${ }^{217}$

In Jones, the Court found the government searched defendant's property because, by placing the GPS receiver on the defendant's vehicle and tracking it, it "physically occupied private property for the purpose

\footnotetext{
212. Id.

213. Id

214. See Kendra Rosenberg, Location Surveillance by GPS: Balancing an Employer's Business Interest with Employee Privacy, 6 WASH. J. L. TECH. \& ARTS 143, 144 (2010) ("Employers are beginning to use Global Positioning System ("GPS”) navigation devices more frequently as a practical tool to monitor employees' locations.”).

215. Elgin v. St. Louis Coca Cola Bottling Co., No. 4:05CV970-DJS, 2005 WL 3050633, at*34 (E.D. Mo. Nov. 14, 2005); see also Alexandre v. N.Y.C. Taxi \& Limousine Comm'n, No. 07CV8175(RMB), 2007 WL 2826952, at *9 (S.D.N.Y. Sept. 28, 2007) (denying preliminary injunction for employee's claim that employer's GPS use was an invasion of privacy).

216. Elgin, 2005 WL 3050633, at *3 (quoting United States v. Knotts, 460 U.S. 276 (1983)).

217. 132 S. Ct. 945, 947 (2011).
} 
of obtaining information."218 It noted, however, that its decision did not alter precedent establishing that the government's mere visual observation of a vehicle on public roads is not a search, as a "person traveling in an automobile on public thoroughfares has no reasonable expectation of privacy in his movements from one place to another."219 The majority opinion did not reach the question of whether "achieving the same result through electronic means [such as longer term monitoring with GPS], without an accompanying trespass, is an unconstitutional invasion of privacy."220

Five Justices in two concurring opinions did opine, however, that "longer term GPS monitoring in investigations of most offenses impinges on expectations of privacy." ${ }^{221}$ These Justices took the attributes of GPS monitoring into account when considering a societal expectation of privacy in the sum of one's public movements. ${ }^{222}$ "GPS monitoring generates a precise, comprehensive record of a person's public movements that reflects a wealth of detail about her familial, political, professional, religious, and sexual associations." ${ }^{223}$ Justice Sotomayor further opined:

[I]t may be necessary to reconsider the premise that an individual has no reasonable expectation of privacy in information voluntarily disclosed to third parties. This approach is ill suited to the digital age, in which people reveal a great deal of information about themselves to third parties in the course of carrying out mundane tasks. ${ }^{24}$

An explicit balancing of interests under the approach outlined in Part III would assist a court analyzing whether an employer intrudes on an employee's seclusion if it surreptitiously monitors employees using GPS.

218. Id. at 949 .

219. Id. at 953 (quoting Knotts, 460 U.S. at 281).

220. Id. at 954. The Jones majority found that the government's placement of a GPS receiver on a vehicle and its use of the device was a trespass. When an employer owns the vehicle it tracks with GPS, placing the GPS receiver on it without the employee's consent would not be a trespass.

221. Id. at 955, 964 (Sotomayor, J., concurring); id. at 964 (Alito, Ginsberg, Breyer, and Kagan, JJ., concurring in the judgment).

222. Id. at 956 (Sotomayor, J., concurring); id. at 963-64 (Alito, Ginsberg, Breyer, and Kagan, JJ., concurring in the judgment).

223. Id. at 955 (Sotomayor, J., concurring); see also United States v. Maynard, 615 F.3d 544, 562 (D.C. Cir. 2010) ("A person who knows all of another's travels can deduce whether he is a weekly church goer, a heavy drinker, a regular at the gym, an unfaithful husband, an outpatient receiving medical treatment, an associate of particular individuals or political groups-and not just one such fact about a person, but all such facts.”), aff'd in part sub nom. United States v. Jones, 132 S. Ct. 945 (2012).

224. Jones, 132 S. Ct. at 957 (Sotomayor, J., concurring) (citations omitted). 
Consider an employer that allows an employee to use an employerowned vehicle on work and personal time. What if the employer investigates suspected wrongdoing by tracking the employee with GPS? Assume the employer did not notify the employee of the monitoring because it would undermine the investigation. Would it be an intrusion on seclusion if the employer tracked the employee on work and personal time? Under the approach in Part III, a court would first determine whether an employee had a reasonable expectation of privacy or zone of privacy in the sum of her movements in an employer-owned vehicle on public roads. It would be difficult for the employee to claim a reasonable expectation of privacy while on company business, but it might be possible to establish a zone of privacy around the sum of one's movements on public roads while off duty (the employee would have to distinguish observing a person on a public street from the comprehensive record GPS monitoring can produce). If a court found the sum of the employee's movements on public roads while off-duty to be a private matter, the court would next determine whether the GPS monitoring was highly offensive to a reasonable person by balancing the employer's business need for the information against the employee's privacy interest. Whether the GPS monitoring was an actionable invasion would be highly dependent on the specific facts.

\section{Thwarting Commission of the Tort}

If an employee refuses to permit the employer's intrusion, she may not recover for intrusion on seclusion even if the employee's refusal resulted in discipline. In Gretencord v. Ford Motor Co., the federal District of Kansas refused to allow a Ford employee to recover for an invasion that never took place. ${ }^{225}$ Ford had a policy requiring employees to submit to random vehicle searches when exiting company lots. ${ }^{226}$ Failure to submit would result in lost parking privileges and discipline. ${ }^{227}$ Ford security officers subsequently tried to stop plaintiff's vehicle; plaintiff refused to submit to the stop and never submitted to a search. ${ }^{228}$ Ford then took away his parking privileges and a portion of his pay. ${ }^{229}$ The court did not opine on the propriety of the discipline, but found

\footnotetext{
225. 538 F. Supp. 331, 333 (D. Kan. 1982).

226. Id. at 332.

227. Id

228. Id.

229. Id.
} 
plaintiff had thwarted the commission of a tort and, therefore, he could not recover for damages that never occurred. ${ }^{230}$

\section{J. Consent}

As mentioned, consent is a complete defense to intrusion upon seclusion, and it may be inferred from the circumstances. But whether and to what extent an employee has consented to an intrusion on seclusion can be difficult to discern. ${ }^{231}$ An employee does not consent to every intrusion simply by accepting employment. On the other hand, a court may infer consent even if an employee acceded to the employer's demands because she faced discipline. Exploring consent in the employment context requires a separate article; the following paragraphs simply summarize two Kansas cases on the subject. ${ }^{232}$

When an employee consents to an employer's investigation of her conduct, no actionable invasion occurs when the employer interviews employees and otherwise seeks information within the parameters of the

230. Id. at 333; cf. Pascouau v. Martin Marietta Corp., No. 98-1099, 1999 WL 495621, at *14 (10th Cir. July 14, 1999) (noting under Colorado law, liability attaches only to unconsented invasions "that actually glean private information").

231. Courts have considered whether an employee consented to an invasion in other types of privacy tort claims. For example, in Johnson v. Boeing Airplane Co., an employee objected to Boeing's unauthorized publication of his picture in company promotional materials and published advertisements. 262 P.2d 808, 809 (Kan. 1953). The court found the employee impliedly consented to his photograph being used while he was employed. Id. 813-14. The outcome was just the opposite, however, in a remarkably similar case against Boeing almost fifty years later. In Dry $v$. Boeing, Boeing again used a picture of an employee in promotional and advertising materials without the employee's authorization. No. 99-1402-WEB, 2002 WL 31730924, at *1 (D. Kan. Sept. 3, 2002). In Dry, however, Boeing continued to use the employee's photograph even after it fired the employee. Id. The court found this fact distinguished it from Johnson and would not imply, as a matter of law, the employee's consent to use the photograph once the employee no longer worked for Boeing. Id. at *3. The "less than friendly" circumstances of the employee's termination raised a genuine issue of fact whether consent was limited to the employment term or whether a reasonable employer would understand the employee's prior consent was limited or revoked. Id.

232. The tentative draft of the Restatement (Third) of Employment Law takes the position that employee consent obtained as a condition of obtaining or retaining employment is "not sufficient to provide a defense" to an intrusion on seclusion claim. See $\S 7.06 \mathrm{cmt}$. g. This position would appear to conflict with federal cases applying Kansas law, as they have found consent even when an employee was faced with a Hobson's choice of either consenting to the intrusion or facing discipline or termination. However, the tentative draft acknowledges:

[I]t is an oversimplification to say that consent can be disregarded in the employment context. Some types of employment require reduced expectations of privacy, whether for reasons of safety, efficiency, or societal norms. By taking a type of employment with notice of the expectations as to privacy, the employee effectively consents to the reasonable requirements of the position, which may entail a reduced expectation of privacy. 
consent. $^{233}$ In Curtright, also discussed in Part V.C.3, the court inferred an employee's consent to an investigation of his conduct and then refused to find any intrusion based on that investigation. ${ }^{234}$ The court did not specify which facts indicated voluntary consent, so one cannot draw any broad conclusions from this case.

Frye v. IBP, Inc., also discussed in Part V.B., affirmed that an employee does not consent to all privacy invasions merely by accepting employment. ${ }^{235}$ It also indicated, however, that consent may be inferred even if the employee faces the threat of discipline or termination. ${ }^{236}$ The employer in Frye required an employee provide a urine sample for a drug test. $^{237}$ The employee complied, was fired, and then challenged the test as an intrusion on seclusion. ${ }^{238}$ The Frye court agreed with the employer that consent to a drug test may be inferred when an employee provides a urine sample on request, and the inference is not negated when refusal to consent will result in termination or discipline. ${ }^{239}$ But even though the employee submitted to the test, the court did not find the employee's consent was voluntarily given. Instead the court found that an employee does not implicitly agree to any and all demands her employer makes as to drug testing simply by accepting employment. ${ }^{240}$ The consent will be limited by the employer's stated policy on testing. The employer's drug testing policy in Frye stated it would test an employee if it had reasonable suspicion that the employee's ability to function safely was affected by alcohol or drugs. Because the employer did not have reasonable suspicion the employee's ability to function safely was affected, it did not have plaintiff's voluntary consent to test. ${ }^{241}$

Id.

233. Curtright v. Ray, No. 90-2034-V, 1991 WL 179385, at *7 (D. Kan. Aug. 23, 1991).

234. Id.

235. 15 F. Supp. 2d 1032, 1042 (D. Kan. 1996). Whether consent is a defense to the intrusion or whether plaintiff must prove lack of consent is not clear. See Entrikin, supra note 3. The Curtwright court seemed to place the burden on plaintiff to show lack of consent to prove the information sought was private.

236. Frye, 15 F. Supp. 2d at 1041

237. Id. at 1037.

238. Id. at 1038.

239. Id. at 1041.

240. Id. at 1042.

241. Id. The court did, in any event, approve the test as reasonable even though the employer did not follow all aspects of its policy. The test was not highly offensive to a reasonable person because it was justified by the employer's stated purpose of maintaining a safe place to work. Id. at 1042-43. 


\section{CONCLUSION}

Kansas courts have not yet developed a clear approach to intrusion on seclusion claims in the employment context. A clear approach to these claims must involve a balancing of employer and employee interests. As in the collections context, an intrusion on seclusion analysis in the employment context must recognize that each party's rights are qualified. An employee's right to privacy is qualified by the employer's legitimate business interests, and the employer's right to pursue its legitimate business interests is qualified by the employee's right to privacy. To determine if an employer's invasion of an employee's zone of privacy is highly offensive, courts must determine whether the employer's business interest justifies the scope and manner of its invasion. This balancing of interests in the employment context is consistent with Kansas intrusion on seclusion law, with several other states' treatment of inclusion on seclusion in the employment context, and with privacy analysis in the employment context under federal law. In existing federal cases analyzing Kansas law, courts have implicitly, if not explicitly, balanced the parties' interests. An explicit balancing will, however, develop the law more clearly in the future and provide better guidance to employers and employees. 